\title{
Mellemrum to - køn, etnografi og psykologi
}

\author{
Af Dorthe Staunes, \\ Rasmus Prastmand Hansen \\ og SEbastian MOHR
}

\section{MELLEMRUM}

Dorthe Staunæs er professor MSO på Institut for Uddannelse, Århus Universitet. Med en baggrund i socialpsykologien og minoritetsstudier forsker hun i de performative og subjektskabende effekter af bestemte typer af ledelse herunder mangfoldighedsledelse og psy-ledelse i uddannelseskontekster, særligt skolen. Siden ph.d.-afhandlingen Køn, etnicitet og skoleliv (2004) har hun haft skolen i centrum for sit etnografiske arbejde, og hvordan der her produceres og ledes gennem affektivitet samt sociokulturelle kategorier som køn, etnicitet og race. Temaredaktionen mødtes med Dorthe Staunæs i december 2015 på café i København for at tale om hendes levede akademiske liv og de teoretisk-analytiske potentialer, som opstår gennem etnografisk kønsforskning, når fokus rettes mod subjektivering, affekt og skoleledelse.

\section{KØN TVINGES OG TÆNKES FREM -} AKADEMISK TILBLIVELSESHISTORIE

Køn var bestemt ikke en del af psykologistudiet på Københavns Universitet i 90-erne. Måske er det anderledes i dag. På pensum var meget lidt om køn, men lidt om kønsroller. Vi læste Nancy Chodorows The Reproduction of Mothering (1978) og Hanne Haavinds Liten og stor: modres omsorg og barns utviklingsmuligheter (1987). Det var noget jeg og medstuderende selv fandt frem. På overbygningen handlede det meste om, om ulighedsdiskussioner kunne klares gennem en opmærksomhed på social klasse og marginalisering. Her læste vi Helle Andersen, Frigga Haug og Ute Osterkamp, dvs. dansk-tysk marxistisk funderet psykologi sammen med Foucaults Overvågning og straf. Først mod slutningen af studiet blev jeg så opmærksom på det engelske 'psychosocial' miljø omkring tidskriftet Feminism of Psychology, kønsforskningsmiljøet i Oslo omkring Hanne Haavind og de mere poststrukturalistiske og socialkonstruktivistiske tilgange. Min optagethed af køn forsøgte 
jeg sideløbende at få stimuleret akademisk ved at besøge seminarer og konferencer på Nina Lykkes' kønsstudier på det daværende Odense Universitet, og jeg byttede 'normaliseringsfagene' klinisk psykologi og arbejdspsykologi ud med minoritetsstudier på Københavns Universitet. Det afspejler en interesse i ikke blot køn, men i diversitet i det hele taget. En undren over det, der ikke bare kunne passere uantastet, eller det, der hele tiden faldt uden for givne rammer og kliniske diagnoser. Det, der ikke rigtigt kunne være der, og som tit kom til at hedde noget med køn eller med race eller med etnicitet. Så jeg fik oparbejdet et blik for normativitet og normkritik og brugte det i min kandidatuddannelse. Mange af dem, jeg læste psykologi sammen med, er siden hen blevet forskere og har et stort socialt og politisk engagement, men de var faktisk ikke optaget af sociale kategorier som køn, etnicitet og race; og blandt nogle af underviserne blev jeg til 'hende der køn- og kulturdamen'. Køn, kultur, etnicitet og race blev opfattet som svært at beskæftige sig med. Man ville ikke være med til undertrykkelse, hvorfor en del kritisk, psykologisk forskning var kendetegnet ved bestræbelser på almengørelse, men samtidigt også farve- og kønsblindhed. Der havde været nogle på psykologistudiet før mig, som interesserede sig for køn, men de var 'eksileret' til Norge eller til praksis. På den måde havde der altså været en interesse for køn i det danske psykologiske miljø, men der blev ikke i særlig høj grad teoretiseret over sociale kategorier som processuelle eller $\mathrm{k} ø \mathrm{n}$ som mere end forskel førend Dorte Marie Søndergaards Tegnet på kroppen - Køn: koder og konstruktioner blandt unge voksne $i$ Akademia (1996). Der er jo en lang tradition i psykologien for, på den ene side, normalisering og standardisering, og, på den anden side, oprør mod kultur og normer og solidaritet med udstødte. Men jeg gik nogle andre steder hen med min interesse for køn og diversitet og fik her andre redskaber til at arbejde normkritisk og kategorisensitivt.
FORSKNINGSLIV OG FOTOGRAFIER ETNOGRAFISK ARBEJDE OM BØRNELIV OG LEDELSESFORMER

Op til og i arbejdet med Transitliv - andre perspektiver på unge flygtninge (Staunæs 1998) var jeg ret optaget af det passende og ikke passende, det normale og det ikke normale. Det er klart, at noget af det har handlet om mig selv (jeg har altid opfattet mig som intern nomade), men selvfølgelig også om en samfundsmæssig interesse. Asyllejren er samfundets ultimative liminalitetszone: du er simpelt hen i det her grænseland, mellem kategorier, hverken inde eller ude. I forhold til at forstå mellemrum og andethedsproblematikker, så er asyllejren jo simpelt hen koncentratet af det hele. På dette tidspunkt, omkring 1993, hvor jeg begyndte at tænke nærmere på det, der kom de bosniske flygtninge hertil. De blev indkvarteret i midlertidige lejre og nogle endda på Flotel Europa, et skib i havnen, så de ikke en gang var i land. Asyllejren blev et sted, som kunne indkredse diskussionen omkring: hvad betyder andethed, hvad betyder udgrænsning, og hvordan håndterer mennesker at leve med det. Det tror jeg egentlig har været ret gennemgående for det, jeg har været optaget af, at jeg sådan ret tidligt har stiftet bekendtskab med teorier, som har tilladt mig at tænke i andetgørelse og majorisering/minorisering som del af subjektiveringsprocesser. Det havde jeg ikke begreb for på det tidspunkt, men jeg kan godt se, det er det, jeg har ledt efter: Hvad er det for nogle styringer, der gør, at mennesker er i de situationer og kontekster, som de er i, hvem/hvad bliver de til, og hvordan håndterer de effekterne af det, og hvordan er hele dette kompleks kønnet, etnicificeret og racialiseret. Jeg lavede derfor feltarbejde i en børne- og familielejr over knap et år, men jeg anede ikke, hvordan jeg skulle tale med de asylansøgende børn, for vi havde jo ikke det samme sprog. I den familie- og børnelejr, jeg besøgte, var der børn fra Afghanistan, Kosovo og Somalia og nogle enkelte børn fra 
Bosnien. Men jeg havde venner, der var fotografer og arbejdede med film, og så tror jeg, vi ligesom kom den vej rundt: Man kan jo kommunikere gennem billeder; og man kan give dem et kamera og bede dem om at 'skyde tilbage fra reservatet' (Hubbard 1994). Den form for visuel metodeudvikling findes også i psykologi - og terapi for den sags skyld, som jeg ikke var synderligt interesseret i den gang - men jeg var interesseret i, hvilke teknikker man bruger til at komme i kontakt med andre mennesker. Det tror jeg måske er en anden gennemgående ting, det der med, at jeg er faktisk nysgerrig på, hvad er det for nogle andre historier, oplevelser og erfaringer andre har, og som jeg ikke umiddelbart kender. Så derfor tog jeg fat i Kodak og Egmontfonden og fik dem til at donere de her engangskameraer, som på daværende tidspunkt lige var kommet frem. Jeg troede helt ærligt, jeg var den eneste i verden, der havde fundet på det. Jeg tænkte, hold kæft, det her det er smart. Det er siden gået op for mig, at jeg var med på en tendens. Lige præcis på det tidspunkt, der eksploderede brugen af engangskameraer over hele forskningsverdenen.

Samtidig brugte jeg mig selv som et etnografisk instrument. Jeg blev faktisk ret berørt af at være der. Det var sindssygt hårdt. For eksempel var der unge, der gik ud i skoven, når de havde fået afslag på asyl og prøvede at tage livet af sig. Der var forældre, som lå i en seng hele dagen og ikke kunne bevæge sig, fordi de havde efterladt børn de steder, de var flygtet fra, og der var børn, der hele tiden forsøgte at cope med det sværeste. Når man bruger sig selv som etnografisk instrument, så prøver man at tune sig følelsesmæssigt ind på: "Hvad er det, der foregår her”. Så det er et forsøg på at stemme sig og finde ud af "hvad foregår der her?" "Hvordan føles det?". Man skal samtidig kunne skelne imellem at bruge sig selv som et instrument i empiriproduktionen og så at kunne gå ud derfra og gå hjem og være analytisk. Jeg skruede altså op for en bestemt form for sensibilitet, når jeg var i lejren, for at finde ud af, hvordan det er at leve i en asyllejr, samtidigt med at jeg jo var klar over, at jeg aldrig nogensinde vil komme til at erfare deres erfaringer. Denne oparbejdede sensibilitet kunne jeg dog ikke bare, selv om jeg hoppede ind i toget og tog hjem, smide af igen, fordi det jo sad i kroppen på mig.

Efter Transitliv, hvor jeg var ude i 'grænselandet', hvor den politiske styring går på at skabe midlertidighed og afgrænsning, tænkte jeg på, hvordan mon andethedsproblematikken ser ud sådan et sted, hvor det er meningen, at der skal inkluderes og produceres mennesker, der skal blive ved med at være en del af det her samfund; altså hvilke menneskelige tilblivelser er overhovedet mulige her. Den danske folkeskole måtte simpelthen være sådan et sted. Den har været dansk nationalitetsproducerende per se. På det tidspunkt - i 1998 tror jeg - var kulturel diversitet, modersmålsundervisning og mangfoldighedsledelse et kæmpe tema. Det blev jeg meget optaget af og designede et forskningsprojekt, som havde to skoler i fokus, der gjorde noget meget forskelligt politisk og ledelsesmæssigt, men egentlig hentede børn fra nogenlunde det samme boligområde, for at undersøge: "Hvordan kan man blive menneske eller elev her?" Og hvordan er elevtilblivelserne vævet sammen med køn, etnicitet og race? Ligesom i asyllejren brugte jeg engangskameraer for at få børnene til at fortælle deres skoleliv via metoder, som i høj grad tilgodeså, hvad de og jeg selv havde af kommunikative evner.

I mit etnografiske feltarbejde mærkedes det tydeligt, at der var bestemte og obligatoriske normativiteter, der handlede om etnicitet, race og køn, og jeg blev optaget af, hvordan disse normativiteter vævede sig ind i hinanden, understregede og spændte ben for hinanden. Fx blev jeg smidt ud af 5 . klasse og kom på kontoret, fordi jeg administrerede min voksenhed forkert: jeg lavede aftaler med eleverne udenom lærerne og 
sagde at eleverne ikke behøvede at vise deres fotos til andre. Sådanne normativiteter, der vævede sig sammen med køn-etnicitetrace regulerede livet på begge skoler, men de blev løsnet og strammet på forskellig vis, alt efter hvilken ledelse og politik, der blev udført på den enkelte skole. Det er faktisk derfor, jeg blev så optaget af at undersøge ledelse som fremomen bagefter. Der er simpelt hen et eller andet med de her styringsog ledelsesformer, som er med til at bestemme på nogle ret subtile måder, hvordan det egentlig er, vi kan blive til som mennesker. Det var helt tydeligt, der var simpelt hen noget, som jeg ikke vidste her, eller noget, som jeg blev nødt til at vide noget mere om. Ledelsesinteressen blev yderligere understøtte $\mathrm{i}$ et projektet med Dorte Marie Søndergaard i en større dansk virksomhed, der handlede om, hvorfor der ikke kommer kvinder op i ledelsestoppen. Det feltarbejde begavede os med et blik på, hvordan bestemte og smalle ledelsesforståelser passer som hånd $\mathrm{i}$ hanke til bestemte og smalle transnationale business-orienterede maskuliniteter, og noget af vores feltarbejde bestod fx i at følge med på intranettet, hvor vi kontinuerligt kunne se, hvem der var fyret og hyret, og dermed også ane hvilke forestillinger om rigtighed, der blev ledt efter.

Efter ph.d.-afhandlingen begyndte jeg og mine kolleger Malou Juelskjær og Helle Bjerg at få øje for alle de her ledelsesteknologier - vi kaldte det på det tidspunkt tekno-terapeutiske instrumenter - som fx elevsamtaler, komfortteknologier og miljøterapeuter som ledelsesagenter - der var informeret af såvel den moderne psykologi som af post-psykologien, hvor vores analytiske tilgang til det så var, at ledelsesteknologier ikke blot møder eller repræsenterer mennesker. De er performative og skaber mennesker, sociale kategorier og følelser og forståelser. De skaber psy-ontologier.
NÅR MENNESKER AFFICERER

OG AFFICERES -

\section{LABORATORIET VENDER TILBAGE}

Mange af de ledelsesteknologier, der sættes i gang i dag, går udenom refleksionen og samtalen og direkte på sanser, rytmer, affekter og stemninger. Det kan fx være i de måder, hvorpå man orkestrerer et læringsmiljø, et såkaldt affektivt edu-scape. Og det er så der, vi begynder at snakke om styringsformer som environmentality, dvs. som ledelse der går på det konstitutive 'moment før' og altså på de betingelser og præmisser, der skaber organisationens psykologiske fænomener. Denne form for ledelse kræver en etnografisk feltarbejder, der lader sig afficere og tilgå (egne og andres) sanser og fornemmelser forskningsmæssigt, og en feltarbejder der inviterer mere xstetiske tilgange ind.

De typer af etnografisk feltarbejde, jeg laver aktuelt, betegner jeg som laboratorier. For 15-30 år siden var jeg sjovt nok en del af den strømning inden for psykologi, som var et opgør med laboratoriet som udforskningsform. Det var et opgør med en bestemt positivistisk måde at tænke $\mathrm{i}$ at rense og kontrollere objektet. Disse eksperimenter og laboratorier er i den grad blevet kritiseret for ikke at anerkende designets egen medvirken til forsøgets resultater. Derfor ville vi ud i virkeligheden - $\mathrm{fx}$ ud $\mathrm{i}$ asyllejren - og se på det levede liv i alt dets kompleksitet. De aktuelle laboratorier er ikke en tilbagevending til de gamle, men en vending med de erkendelser, som kritikken gav, og som pegede på hvordan forskning ikke blot afspejler verden (reflekterer) den, men er med til at sætte og bevæge den gennem sine greb og metoder. Jeg arbejder med at gentænke det socialpsykologiske laboratoriebegreb på to forskellige måder. Den første handler om at undersøge en række showcases vedrørende ledelse på fx motivation eller inklusion 'ude i virkeligheden' og at iscenesætte disse som generaliserede, etnografiske laboratorier, hvor man kan udforske professionelle og lederes 'live' ekspe- 
rimenter med forskellige teknologier og praksisser og fx visuelt og auditivt undersøge, hvordan det afficerer de mennesker, der bebor organisationen. Det lab-design giver os mulighed for at undersøge de performative effekter af ledelse eksemplarisk. Det andet format er en slags pop-up laboratorium, et midlertidigt læringslaboratorium, hvor vi sammen med professionelle og ledere undersøger, eksperimenterer med, teoretiserer over og udvikler deres ledelsespraksisser ved at skrue op og ned for bestemte betingelser og temaer og ved at lege med fremstillingsformer som fx improvisation. I begge formater handler det ikke om at repræsentere verden, men om at være del af $o g$ i relation til den, at røre og afficere den gennem nye begreber, forsøgsopsætninger og instrumenter, og om at undersøge hvad der så sker. Man kan sige, at vi tager Haraways problematisering af det beskedne vidne meget bogstavligt. Forskerne er ikke beskedne vidner men deltagere, der faciliterer og med-konstruerer et materielaffektivt-semiotisk forundringsrum, et 'wunderkammer', som Jette Kofoed og jeg har kaldt det (Staunæs \& Kofoed 2015a, 2015b). Laboratorie-set-uppet muliggør på den måde både eksperimenterende ledelse og eksperimenterende forskning, og det kræver nye måder at tænke og eksperimentere med kritik på (Juelskjær \& Staunæs forthcoming). Kritik kan her ikke formuleres ude fra, men må altid tage sine egen indlejrethed med og gøre sine håb og bekymringer tydelige. Derfor sker der også et skift mod en affirmativ kritikform, der vægrer sig mod moralisme, men forsøger at finde 'andre steder' og samtidig holde sig for øje, om der er nogle/noget, der er mere udsatte i denne søgende bevægelse end andre. Den forskning, jeg er involveret i aktuelt, har på den måde et andet format og er et helt andet konkret forpligtende indspark, hvor man forsker i 'mode tre' eller 'fire'. Jeg tror ikke, jeg har ord for, hvad det er endnu, eller hvad konsekvenserne er. Det er ufærdigt, men jeg ser en del kolle- ger, der forsøger sig med lignende gentænkninger af såvel forskningsdesign som kritikbegreber.

\section{KøNS(UD)FORSKNING MELLEM DET PASSENDE OG UPASSENDE}

I en del af kønsforskningen og feministiske miljøer beskæftiger vi os jo også med alt muligt andet end lige køn. Jeg oplever stadig, at vi i den danske offentlighed og i akademia er forklaringskrævende og ikkeselvfølgelige. Vi kan godt arbejde med køn, kønsteorier og feminisme, men vi må samtidig gøre os relevante i forhold til nogle af de diskussioner, der kører allerede. Så kan man arbejde det kønnede ind, tviste til spørgsmål om magt- og majorisering vha. feministisk teori, queer-teori og posthumanistiske metodologier. Forskningspolitisk er vi også nødt til at være genkendelige og relevante (på andre måder) for de dagsordener, der allerede er sat. Ikke at forstå sådan, at vi skal møde de satte dagsordener i forholdet en-til-en, men forstået sådan, at vi kan hacke os ind på det, der allerede er, dreje det og samtidig netop finde nye formater for problematisering, samarbejder og kritik. Disse former for flersprogethed og hybrid-tænkning og forsøgene på at finde alternative formater kan være livsbekræftende og konstruktive. Men det kan også blive umådeligt anstrengende og til tider farligt at gøre det skævt, når man ikke kan findes på de tilgængelige kort over verden og allerede givne positioner. Det kan give hårde knubs, men omvendt også tendere til, at man bare glider ud og bliver irrelevant. Den skævhed er vel en del af det feministiske arvegods, og det kan anspore til yderligere forskning, aktivisme og (selv)refleksion. Jeg kan ikke så godt lide at ikonisere bestemte tekster, men der er tekster, som jeg bliver ved med at vende tilbage til - og som netop har den pointe - såsom Donna Haraways "The Promises of Monsters: A Regenerative Politics for Inappropriate/d Others" (1992). Den kan jeg blive ved 
med, den er en utrolig tekst, man kan blive ved med at læse sine overvejelser og strategier om upassendehed og alternative 'somewheres' igennem, når etnografien skal designes til at udfordre de (hvide) refræner, der løber igennem vores liv og organisationer.

\section{LITTERATUR}

- Chodorow, Nancy (1978): The Reproduction of Mothering. University of California Press, Oakland. - Haavind, Hanne (1987): Liten og stor: mødres omsorg og barns utviklingsmuligheter. Universitetsforlaget, Oslo.

- Juelskjær, Malou \& Staunæs, Dorthe (2016 forthcoming): Designing leadership chairs: Experiments with affirmative critique of leadership and environmentality, in: RERM, Reconceptualising Educational Research Methodologies.

- Haraway, Donna (1992): The Promise of Monsters: A Regenerative politics for Inappropriate/ed
Others, in: Lawrence Crossberg et al.: Cultural Studies. Routledge, London.

- Hubbard, Jim (1994): Shooting Back from the Reservation: A Photographic View of Life by Native American Youth. The New Press, New York. - Staunæs, Dorthe \& Kofoed, Jette (2015a): Producing curious affects: visual methodology as an affecting and conflictual wunderkammer, in: International Journal of Qualitative Studies in Education $/ 28$ (10).

Staunæs, Dorthe \& Kofoed, Jette (2015b): Experimenting with affects and senses : a performative pop-up-laboratory (self) critically revisited, in: Timm Knudsen \& Carsten Stage (eds.): Affective methodologies: developing cultural research strategies for the study of affects. Palgrave Macmillan, Basingstoke, Hampshire.

- Staunæs, Dorthe (2004): Køn, etnicitet og skoleliv. Forlaget Samfundslitteratur, Frederiksberg. - Staunæs, Dorthe (1998): Transitliv : Andre perspektiver på unge flygtninge. Politisk revy, København.

- Søndergaard, Dorte Marie (1996): Tegnet på kroppen. Køn: koder og konstruktioner blandt unge voksne i Akademia. Museum Tusculanum, København. 